\title{
COVID-19's influence on the credit risks and enterprise innovation of the Guangxi manufacturing Based on the measure of KMV model
}

\author{
LiJun Shen ${ }^{1, \mathrm{a}}$, Yu He ${ }^{2, \mathrm{~b}}$ \\ ${ }^{1}$ Guangxi Financial Vocational College,Xi Xiangtang,Nanning,Guangxi,China \\ ${ }^{2}$ Guangxi Branch of China Development Bank, QingXiu,Nanning,Guangxi,China
}

\begin{abstract}
The paper used the KMV model to manufacturing industry of Guangxi in China to concretely abstract the credit risk and enterprise innovation into a measurable quantitative index, and compare the changes in credit risk before and after COVID-19. This paper selects 17 Listed Companies in Guangxi manufacturing industry as empirical samples, and calculates the expected default rate of different companies by using the traditional and modified KMV models. The larger the index value is, the higher the credit risk is, And then affect the enterprise innovation activities. The results show that the overall credit risk management ability of Guangxi's manufacturing industry is relatively high, but by the impact of COVID-19, credit risk has increased. If left unguarded, it will have an impact on enterprise innovation.
\end{abstract}

\section{Introduction}

This paper provides default risk indicators for Guangxi's manufacturing industry to compare the changes in credit risk before and after COVID-19. As we all known, the contract is the guarantee for the buyer, the seller and other roles to smoothly carry out capital transactions in the market. When the counterparties can't bear the risks in the contract, or the borrower fails to repay the loan in time after the due date, it will cause certain economic losses to the other party of the contract. This situation is called credit risk, or default risk. There are many reasons for this phenomenon, such as asymmetric information, complex financial market participants, inconvenient management, large quantity and amount of transaction, low entry threshold, imperfect incentive and punishment system, and so on. Credit risk often brings imme asurable consequences to investors and enterprises themselves, and even to the whole industry and society. In the normalization of COVID-19 today, it is particularly important to measure credit risk, strengthen early warning,improve risk management ability and enterprise's technical innovation ${ }^{[1]}$.

As for the measurement of credit risk, in the early days, it was mainly through the relevant financial data of enterprises to determine their credit degree and risk-taking ability. This method of observing the static value has been used up to now. Modern credit evaluation model has been widely used since it appeared. Altman (1968) proposed a Z-score Model, which creates a Z-value based on different indicators such as working capital, total assets, equity market value and sales revenue, and stipulates that the critical value of borrower's default is 2.675 . When it is less than this value, it indicates that the borrower's credit risk is high and is divided into default risk group. Otherwise, when it is greater than this value, it is non-default group. Wang Lilin and Shan Yukun (2017) used the Z-value method to measure the credit risk of Listed Companies in China's coal industry ${ }^{[2]}$. Another example is the credit $5 \mathrm{C}$ scoring method, which evaluates the credit risk from five different perspectives of the borrower or company's moral character, operating ability, asset mortgage status, capital and economic environment. Wang Mengqi (2017) proposed the "7C $+\mathrm{G}+\mathrm{P}$ " method to evaluate the credit risk on the basis of this method ${ }^{[3]}$.Jiang Liu (2019) used Cox model to predict the financial credit risk of China's manufacturing supply chain ${ }^{[4]}$.This paper chooses KMV model, which can get the expected default rate according to the calculation results of various parameters, and then evaluate the credit risk of enterprises. This method not only corrects the subjectivity of $5 \mathrm{C}$ scoring method, but also makes up for the arbitrariness of $\mathrm{Z}$ model, so it can measure credit risk more accurately.

Manufacturing industry is an important indicator to measure a country's productivity level and even comprehensive national strength. It is a comprehensive field covering product manufacturing, design, raw material processing, warehousing and transportation, order management, wholesale and retail activities. Therefore, it is particularly necessary to measure the credit risk of manufacturing industry and provide early

\footnotetext{
* Corresponding author: ${ }^{\mathrm{a}}$ 1203799691@qq.com

b2591867547@qq.com
} 
warning mechanism for enterprises and industries. Since the outbreak of COVID-19, there are not many literatures on the credit risk of manufacturing industry in China. The contribution of this paper is that, in the context of COVID-19's impact on all walks of life in China, we use the revised KMV model and the actual situation of manufacturing companies in Guangxi to measure the credit risk before and after the outbreak. It provides a theoretical reference for financial risk prevention in Guangxi.

The structure of this paper is as follows: firstly, the KMV model is constructed from the preconditions and operation steps of the model; secondly, select the appropriate manufacturing listed companies in Guangxi as the sample empirical, with the help of MATLAB and other tools to get the results; then, we use regression analysis to revise the default point, which is an important parameter of KMV model, and re empirical, and compare with the previous empirical results; finally, the rationality of the modified KMV model is tested and the final empirical conclusion is drawn.

\section{Model building}

\subsection{Model introduction}

KMV company of San Francisco in North America established KMV model in 1997. As soon as it came out, it was widely used by the academic circles. This model is used to estimate the default rate of enterprises and simulate the risk through probability method, which has certain reference significance. In short, KMV model is a semi parametric and semi model method, which uses the idea of option pricing, financial data and market transaction information to evaluate the company's credit risk. The basic idea of the model is: when the expected market value of the enterprise is lower than the face value of the debt that the enterprise needs to pay off, the company will default and break its promise. In addition, the model puts forward the index of default distance, which represents the distance between the expected value of market value and the default point. If the value is smaller, the closer the distance is, the greater the probability of default, or the higher the credit risk is.

\subsection{Prerequisite}

KMV model is developed on the basis of BSM option pricing model proposed by Merton (1974), so KMV model needs to satisfy a series of assumptions of BSM option pricing model. The preconditions of traditional KMV model mainly include the following points :

(1)The basic conditions of BSM model are as follows: the fluctuation of stock price is a random process, allowing short selling, no transaction costs and taxes, separability of securities, no arbitrage, continuity of securities trading, and risk-free interest rate to remain unchanged before the borrower pays off the debt;

(2)When the value of the borrower's assets is greater than the value of its debt, there will be no breach of contract; on the contrary, when the value of the borrower's assets is less than the value of its debt, a default occurs;

(3)The market value of enterprises obeys Brownian motion, and the return of borrowers' assets obeys normal distribution;

(4)The borrower's capital only includes owner's equity, short-term debt, long-term debt and convertible preferred stock;

(5)The change of underlying stock price follows the random process of lognormal distribution;

(6)The event of default occurs only at the time $\mathrm{T}$ on the debt maturity date.

\subsection{Operation steps}

(1)Firstly, by using the Black Scholes option pricing formula, the market value and volatility of enterprise equity, maturity time, risk-free lending interest rate and the book value of liabilities are used to construct equations to estimate the market value and volatility of enterprise assets;

(2)Secondly, according to the company's liabilities, the company's default implementation point is calculated, and the borrower's default distance is calculated;

(3)Finally, according to the corresponding relationship between the default distance and the expected default rate, the expected default rate is calculated.

\section{Model implementation}

\subsection{Sample selection}

This paper selects 17 Listed Companies in the manufacturing industry of Guangxi Zhuang Autonomous Region as the empirical sample, and measures the changes of credit risk level of the industry in recent years with KMV model. The data sources of the sample companies in this paper are all from wind database.

\subsection{Empirical operation}

\subsubsection{Setting of some parameters}

Before the empirical operation, we need to set some parameters reasonably.

(1)About the time of sample selection. Since 2020 was the year when COVID-19 broke out, considering the change of the credit risk level of Guangxi manufacturing industry before and after the outbreak, this paper expands the time range, selects the closing price of each sample enterprise from December 31, 2018 to December 31, 2020 as the empirical basis, and takes a year as the time node to measure the credit risk respectively. Calculate the expected default rate of each sample at the end of 2019 and 2020, that is, within each time point:

$$
\mathrm{T}=1
$$

(2)On the determination of risk-free interest rate. The 
one-year treasury bond interest rate is the risk-free interest rate. Cmnet will announce the interest rate of national debt several times in one year, and calculate the average interest rate in 2019 and 2020 respectively, and then take the average of the two:

$$
\mathrm{r}=0.0249^{[5]}
$$

\subsubsection{Calculate the volatility of stock value $\sigma_{E}$ and the market value of equity $V_{E}$}

(1)Use wind to extract the closing prices of all samples on each trading day from December 31, 2018 to December 31, 2020. Because the stock price satisfies the lognormal distribution, the log return rate of the stock is:

$$
u_{i}=\operatorname{In}\left(\frac{s_{i+1}}{S_{i}}\right)
$$

$S_{i}$ is the closing price of the enterprise on day I.

(2)According to the logarithmic rate of return, the daily volatility rate of return of each sample in each year is calculated $\sigma_{n}$, the calculation formula is:

$$
\sigma_{n}=\sqrt{\frac{1}{n-1} \sum_{i=1}^{n}\left(u_{i}-E\left(u_{i}\right)\right)^{2}}
$$

Among them: $E\left(u_{i}\right)=\frac{1}{n} \sum_{i=1}^{n} u_{i}$, that is the average of the logarithmic return of the stock。

(3)According to the daily volatility of stock, the volatility of equity value is calculated:

$$
\sigma_{E}=\sqrt{N} \times \sigma_{n}
$$

Where: $\mathrm{N}$ is the annual trading day.

(4)Because the domestic has basically completed the reform of non tradable shares ${ }^{[6]}$,therefore, this paper defines that the value of equity is equal to the product of total equity and stock price, and the stock price selects the closing price on the base date (that is, the end of the year).

Therefore, we can use Excel to get the equity value and the volatility of equity value of each sample

\begin{tabular}{|c|c|c|c|c|}
\hline Company & $\begin{array}{c}2019 \\
V_{A} \text { hundred } \\
\text { million } \\
\text { RMB }\end{array}$ & $\begin{array}{l}2019 \\
\sigma_{A}\end{array}$ & $\begin{array}{l}2020 \\
V_{A} / \text { hundred } \\
\text { million } \\
\text { RMB }\end{array}$ & $\begin{array}{l}2020 \\
\sigma_{A}\end{array}$ \\
\hline $\begin{array}{l}\text { Hengyi } \\
\text { Petrochemical }\end{array}$ & 395.57 & 0.33 & 471.25 & 0.46 \\
\hline $\begin{array}{l}\text { Royal Group } \\
\text { ST baling }\end{array}$ & $\begin{array}{l}36.86 \\
39.04\end{array}$ & $\begin{array}{l}0.39 \\
0.66\end{array}$ & $\begin{array}{l}38.03 \\
9.49\end{array}$ & $\begin{array}{l}0.46 \\
0.49\end{array}$ \\
\hline $\begin{array}{l}\text { *Galaxy } \\
\text { Biomedical } \\
\text { Investment } \\
\text { GUILIN LAYN }\end{array}$ & 24.86 & 0.58 & 18.37 & 0.42 \\
\hline $\begin{array}{l}\text { NATURAL } \\
\text { INGREDIGENTS }\end{array}$ & 45.78 & 0.53 & 47.59 & 0.48 \\
\hline $\begin{array}{l}\text { Zanthoxylum } \\
\text { nitridum } \\
\text { Guangxi Fenglin }\end{array}$ & 25.14 & 0.39 & 26.07 & 0.45 \\
\hline $\begin{array}{l}\text { Wood Industry } \\
\text { Group }\end{array}$ & 32.42 & 0.26 & 34.37 & 0.36 \\
\hline
\end{tabular}
company. The results are shown in table 1 .

Table 1 Equity value and equity value volatility of sample companies from 2019 to 2020
Guangxi Hechi

Chemical

12.76

$0.40 \quad 15.60$

0.42

Nanfang Black

Sesame Group

NNSUGAR

Guilin Sanjin

Pharmaceutical

Guilin Seamild

Foods

31.05

0.49

24.55

0.52

19.44

0.46

24.86

0.43

77.43

0.19

88.00

0.32

43.75

$0.32 \quad 45.30$

0.89

Nanning

Chemical

Industry

Guilin Fuda

Oriental Times

Media

16.18

0.29

15.73

0.23

35.30

$0.35 \quad 35.11$

$\begin{array}{lll}14.47 & 0.57 \quad 8.07\end{array}$

Corporation

Liuzhou Iron And

Steel

LiuGong Group

144.80

$0.38 \quad 133.01$

102.43

0.29

108.63

0.31

\subsubsection{Calculate asset value $V_{A}$ and asset value volatility $\sigma_{A}$}

The calculation method of asset value and asset value volatility given by KMV model is as follows:

$$
\left\{\begin{array}{c}
V_{E}=V_{A} N\left(d_{1}\right)-D e^{-r T} N\left(d_{2}\right) \\
\sigma_{E}=\frac{N\left(d_{1}\right) V_{A} \sigma_{A}}{V_{E}} \\
d_{1}=\frac{\ln \left(\frac{V_{A}}{D}\right)+\left(r+\frac{\sigma_{A}{ }^{2}}{2}\right) T}{\sigma_{A} \sqrt{T}} \\
d_{2}=d_{1}-\sigma_{A} \sqrt{T} \\
N\left(d_{n}\right)=\int_{-\infty}^{d_{n}} \frac{1}{\sqrt{2 \pi}} e^{-\frac{x^{2}}{2}} d x
\end{array}\right.
$$

$V_{E}$ and $\sigma_{E}$ has been obtained from the above, $\mathrm{r}$ is the risk-free interest rate, $\mathrm{T}$ is the debt repayment time limit, $\mathrm{D}$ is the default point (that is, the critical value of default behavior of listed companies), which is defined as the book value of the enterprise's debt. The traditional default point selection of long-term debt coefficient is 0.5 , that is, half of the enterprise's short-term debt plus long-term debt, The formula is:

$$
D=S D+0.5 L D \quad(5)
$$

Write the KMV Model Code of MATLAB, and solve the asset value and asset value volatility of the sample company according to the known parameters. The results are shown in table 2 .

Table 2 Asset value and asset value volatility of sample companies from 2019 to 2020

\begin{tabular}{ccccc} 
& 2019 & 2019 & 2020 & 2020 \\
& $V_{A} /$ & $\sigma_{A}$ & $V_{A} /$ & $\sigma_{A}$ \\
Company & hundred & \multicolumn{3}{c}{ hundred } \\
& million & \multicolumn{3}{c}{ million } \\
& RMB & \multicolumn{3}{c}{ RMB }
\end{tabular}

$\begin{array}{lllll}\text { Hengyi } & 855.96 & 0.15 & 973.39 & 0.22 \\ \text { Petrochemical } & 57.95 & 0.25 & 69.99 & 0.25 \\ \text { Royal Group } & 47.51 & 0.54 & 16.02 & 0.29 \\ \begin{array}{l}\text { ST baling } \\ \text { * Galaxy }\end{array} & & & & \\ \begin{array}{l}\text { Biomedical } \\ \text { Investment }\end{array} & 37.80 & 0.38 & 33.99 & 0.23\end{array}$




\begin{tabular}{|c|c|c|c|c|}
\hline $\begin{array}{l}\text { GUILIN LAYN } \\
\text { NATURAL } \\
\text { INGREDIGENTS }\end{array}$ & 53.23 & 0.45 & 60.02 & 0.38 \\
\hline $\begin{array}{l}\text { Zanthoxylum } \\
\text { nitridum }\end{array}$ & 31.00 & 0.32 & 29.96 & 0.39 \\
\hline Guangxi Fenglin & & & & \\
\hline $\begin{array}{l}\text { Wood Industry } \\
\text { Group }\end{array}$ & 41.85 & 0.20 & 42.57 & 0.29 \\
\hline $\begin{array}{l}\text { Guangxi Hechi } \\
\text { Chemical }\end{array}$ & 15.71 & 0.32 & 17.36 & 0.38 \\
\hline $\begin{array}{l}\text { Nanfang Black } \\
\text { Sesame Group }\end{array}$ & 51.96 & 0.29 & 47.71 & 0.27 \\
\hline NNSUGAR & 67.23 & 0.13 & 75.39 & 0.14 \\
\hline $\begin{array}{l}\text { Guilin Sanjin } \\
\text { Pharmaceutical }\end{array}$ & 82.34 & 0.18 & 95.38 & 0.30 \\
\hline $\begin{array}{l}\text { Guilin Seamild } \\
\text { Foods }\end{array}$ & 46.77 & 0.30 & 48.68 & 0.83 \\
\hline Nanning & & & & \\
\hline $\begin{array}{l}\text { Chemical } \\
\text { Industry }\end{array}$ & 16.87 & 0.28 & 16.07 & 0.22 \\
\hline $\begin{array}{l}\text { Guilin Fuda } \\
\text { Oriental Times }\end{array}$ & 44.75 & 0.28 & 45.26 & 0.32 \\
\hline $\begin{array}{l}\text { Media } \\
\text { Corporation }\end{array}$ & 18.54 & 0.45 & 21.31 & 0.17 \\
\hline $\begin{array}{l}\text { Liuzhou Iron And } \\
\text { Steel }\end{array}$ & 285.52 & 0.19 & 401.49 & 0.11 \\
\hline LiuGong Group & 264.88 & 0.11 & 313.47 & 0.11 \\
\hline
\end{tabular}

\subsubsection{Calculate the default distance and the expected default rate}

(1)Default distance

Default distance (DD) means the distance between the asset value of an enterprise and the critical value of default. From the definition, the larger the default distance of an enterprise, the farther it is from the default point, the smaller the possibility of default and the lower the credit risk, and vice versa. The calculation formula of default distance given by KMV company is as follows:

$$
D D=\frac{V_{A}-D}{V_{A} \sigma_{A}}
$$

(2)Expected default rate

Because KMV model assumes that the asset value of a company follows lognormal distribution, the formula of EDF is given as follows:

$$
E D F=1-N(D D)
$$

$N(x)$ is the standard normal distribution function.

It can be seen that, to a certain extent, the expected default rate is negatively correlated with the default distance. The larger the expected default rate is, the lower the credit risk or default risk is, and vice versa. This is the analysis basis and conclusion support for the empirical results of Guangxi manufacturing sample company.

According to the known parameters, the default distance and the expected default rate can be obtained, as shown in table 3.

Table 3 Default distance and expected default rate of sample companies from 2019 to 2020

\begin{tabular}{lllll}
\hline \multirow{2}{*}{ Company } & 2019 & 2019 & 2020 & 2020 \\
& DD & EDF & DD & EDF \\
\hline Hengyi & 2.91 & 0.00 & 2.14 & 0.02
\end{tabular}

\begin{tabular}{lllll}
\hline Petrochemical & & & & \\
Royal Group & 2.55 & 0.01 & 2.14 & 0.02 \\
$\begin{array}{l}\text { ST baling } \\
\text { * Galaxy }\end{array}$ & 1.51 & 0.07 & 1.99 & 0.02 \\
$\begin{array}{l}\text { Biomedical } \\
\text { Investment }\end{array}$ & 1.70 & 0.04 & 2.32 & 0.01 \\
$\begin{array}{l}\text { GUILIN LAYN } \\
\text { NATURAL }\end{array}$ & 1.88 & 0.03 & 2.06 & 0.02 \\
$\begin{array}{l}\text { INGREDIGENTS } \\
\text { Zanthoxylum } \\
\text { nitridum }\end{array}$ & 2.56 & 0.01 & 2.21 & 0.01 \\
$\begin{array}{l}\text { Guangxi Fenglin } \\
\text { Wood Industry }\end{array}$ & 3.79 & 0.00 & 2.72 & 0.00 \\
$\begin{array}{l}\text { Group } \\
\text { Guangxi Hechi }\end{array}$ & 2.51 & 0.01 & 2.39 & 0.01 \\
$\begin{array}{l}\text { Chemical } \\
\text { Nanfang Black }\end{array}$ & 1.99 & 0.02 & 1.87 & 0.03 \\
$\begin{array}{l}\text { Sesame Group } \\
\text { NNSUGAR }\end{array}$ & 2.01 & 0.02 & 2.18 & 0.01 \\
$\begin{array}{l}\text { Guilin Sanjin } \\
\text { Pharmaceutical }\end{array}$ & 5.15 & 0.00 & 3.08 & 0.00 \\
$\begin{array}{l}\text { Guilin Seamild } \\
\text { Foods }\end{array}$ & 3.13 & 0.00 & 1.13 & 0.13 \\
$\begin{array}{l}\text { Nanning } \\
\text { Chemical }\end{array}$ & 3.46 & 0.00 & 4.36 & 0.00 \\
$\begin{array}{l}\text { Industry } \\
\text { Guilin Fuda }\end{array}$ & 2.85 & 0.00 & 2.40 & 0.01 \\
$\begin{array}{l}\text { Oriental Times } \\
\text { Media }\end{array}$ & 1.73 & 0.04 & 2.12 & 0.02 \\
$\begin{array}{l}\text { Corporation } \\
\text { Liuzhou Iron And } \\
\text { Steel } \\
\text { LiuGong Group }\end{array}$ & 2.59 & 0.00 & 2.96 & 0.00 \\
\hline & & 0.00 & 3.04 & 0.00 \\
\hline
\end{tabular}

\subsection{Empirical results}

The average default distance and expected default rate of sample companies are used to measure the change of credit risk level of manufacturing industry in Guangxi Zhuang Autonomous Region from 2019 to 2020, as shown in table 4.

Table 4 average default distance and average expected default rate of sample companies from 2019 to 2020

\begin{tabular}{ccc}
\hline & 2019 & 2020 \\
\hline $\begin{array}{c}\text { Average default } \\
\text { distance }\end{array}$ & 2.69 & 2.42 \\
$\begin{array}{c}\text { Average expected } \\
\text { default rate }\end{array}$ & 0.01 & 0.02 \\
\hline
\end{tabular}

The above table can intuitively reflect that since the outbreak of COVID-19 in early 2020, the default distance of Guangxi manufacturing listed companies has been shortened from 2.685 to 2.418 , while the expected default rate has increased from 0.01497 to 0.01858 , indicating that the manufacturing industry has been hit.

\section{Model improvements}

\subsection{Amendment of traditional default point}

In the above empirical process, the traditional calculation formula of default point is used. However, it should be noted that the origin of KMV model is in the United 
States. If it is appropriate to measure the credit risk of a company or an industry in the United States, this part applies the model to Guangxi manufacturing industry, although it can reflect the level of credit risk to a certain extent, However, China's national conditions are quite different from those of foreign countries, which may lead to the deviation of research results. Shi Dongchao (2019) proposed that the specific selection of default point is not invariable, but should be revised according to different research industries and fields ${ }^{[7]}$. Therefore, it is inappropriate to define default point as the sum of half of short-term liabilities and long-term liabilities, which need to be combined with the actual situation of the industry, Find a suitable default point.

According to KMV's default point, the default point is a linear combination of short-term liabilities and long-term liabilities:

$$
D=\alpha * S T D+\beta * L T D \quad(8)
$$

In order to determine the appropriate default point, this paper selects the total assets, short-term liabilities and long-term liabilities of the sample companies from 2019 to 2020 as variables to build a regression analysis model ${ }^{[8]}$. Total assets are the explanatory variables of the model, short-term liabilities and long-term liabilities are the explanatory variables:

$$
Y=a+b_{1} X_{1}+b_{2} X_{2} \quad \text { (9) }
$$

$Y$ is the total assets and $X_{1}$ is short-term liabilities, $X_{2}$ is the long-term debt, $a$ is the intercept, each variable can be obtained in the wind database. The relevant data are as follows in table 5.

Table 5 regression data of sample companies from 2019 to

\begin{tabular}{|c|c|c|c|c|}
\hline Company & Year & $\mathrm{Y} / \mathrm{RMB}$ & $\mathrm{X} 1 / \mathrm{RMB}$ & $\mathrm{X} 2 / \mathrm{RMB}$ \\
\hline $\begin{array}{l}\text { Hengyi } \\
\text { Petrochemical }\end{array}$ & 2019 & 852.31 & 382.32 & 179.35 \\
\hline Royal Group & 2019 & 49.46 & 18.35 & 6.56 \\
\hline $\begin{array}{l}\text { ST baling } \\
\text { *Galaxy }\end{array}$ & 2019 & 27.10 & 7.75 & 1.87 \\
\hline $\begin{array}{l}\text { Biomedical } \\
\text { Investment } \\
\text { GUILIN LAYN }\end{array}$ & 2019 & 17.19 & 11.72 & 3.11 \\
\hline $\begin{array}{l}\text { NATURAL } \\
\text { INGREDIGENTS }\end{array}$ & 2019 & 26.00 & 6.84 & 1.58 \\
\hline $\begin{array}{l}\text { Zanthoxylum } \\
\text { nitridum } \\
\text { Guanoxi Fenglin }\end{array}$ & 2019 & 26.94 & 5.72 & 0.60 \\
\hline $\begin{array}{l}\text { Wood Industry } \\
\text { Group }\end{array}$ & 2019 & 39.75 & 7.67 & 3.99 \\
\hline $\begin{array}{l}\text { Guangxi Hechi } \\
\text { Chemical }\end{array}$ & 2019 & 3.45 & 2.96 & 0.13 \\
\hline $\begin{array}{l}\text { Nanfang Black } \\
\text { Sesame Group }\end{array}$ & 2019 & 52.99 & 18.29 & 6.30 \\
\hline NNSUGAR & 2019 & 53.42 & 46.06 & 5.89 \\
\hline $\begin{array}{l}\text { Guilin Sanjin } \\
\text { Pharmaceutical }\end{array}$ & 2019 & 34.16 & 4.05 & 1.95 \\
\hline $\begin{array}{l}\text { Guilin Seamild } \\
\text { Foods }\end{array}$ & 2019 & 16.54 & 3.05 & 0.09 \\
\hline $\begin{array}{l}\text { Nanning Chemical } \\
\text { Industry }\end{array}$ & 2019 & 4.01 & 0.63 & 0.16 \\
\hline Guilin Fuda & 2019 & 32.12 & 8.76 & 1.86 \\
\hline $\begin{array}{l}\text { Oriental Times } \\
\text { Media Corporation }\end{array}$ & 2019 & 6.63 & 3.42 & 1.50 \\
\hline
\end{tabular}
2020
Liuzhou Iron And

Steel

$2019 \quad 264.46 \quad 137.53 \quad 13.49$

$\begin{array}{llll}\text { LiuGong Group } \quad 2019 & 298.61 & 142.78 \quad 47.53\end{array}$

Hengyi

Petrochemical

Royal Group

ST baling

*Galaxy

Biomedical

Investment

GUILIN LAYN

NATURAL

INGREDIGENTS

Zanthoxylum

nitridum

Guangxi Fenglin

Wood Industry

Group

Guangxi Hechi

Chemical

Nanfang Black

Sesame Group

NNSUGAR

Guilin Sanjin

Pharmaceutical

Guilin Seamild

Foods

Nanning Chemical

Industry

Guilin Fuda

Oriental Times

Media Corporation

Liuzhou Iron And

Steel

LiuGong Group

$\begin{array}{lll}2020 & 922.60 \quad 410.04\end{array}$

209.64

$2020 \quad 60.59$

$2020 \quad 14.68$

28.19

9.16

$2020 \quad 21.27$

11.39

0.59

9.25

$2020 \quad 31.63$

11.95

1.58

$\begin{array}{llll}2020 & 25.55 & 3.64 & 0.70\end{array}$

$\begin{array}{llll}2020 & 38.34 & 7.55 & 1.71\end{array}$

$\begin{array}{llll}2020 & 3.76 & 1.69 & 0.25\end{array}$

$\begin{array}{llll}2020 & 52.14 & 23.09 & 1.32\end{array}$

$\begin{array}{llll}2020 & 58.25 & 47.92 & 7.79\end{array}$

$\begin{array}{llll}2020 & 38.82 & 5.89 & 3.34\end{array}$

$\begin{array}{llll}2020 & 16.97 & 3.42 & 0.10\end{array}$

$\begin{array}{llll}2020 & 3.73 & 0.29 & 0.11\end{array}$

$\begin{array}{llll}2020 & 33.90 & 9.58 & 1.67\end{array}$

$\begin{array}{llll}2020 & 6.15 & 11.97 & 3.22\end{array}$

$\begin{array}{llll}2020 & 605.95 & 193.38 & 163.74\end{array}$

$\begin{array}{llll}2020 & 340.11 & 199.03 & 21.94\end{array}$

The regression results are as follows in table 6 , table 7 and table 8 .

Table 6 Regression Statistics

\begin{tabular}{lc}
\hline \multicolumn{2}{c}{ Regression statistics } \\
Multiple R & 0.997429 \\
R Square & 0.994864 \\
Adjusted R Square & 0.994533 \\
Standard error & $1.71 \mathrm{E}+09$ \\
\multicolumn{1}{c}{ Observations } & 34 \\
\hline
\end{tabular}

Table 7 Analysis of Variance

\begin{tabular}{llllll}
\hline & df & SS & MS & F & Sig- F \\
\hline $\begin{array}{l}\text { Regression } \\
\text { analysis }\end{array}$ & 2 & $1.75 \mathrm{E}+22$ & $8.76 \mathrm{E}+21$ & 3002.45 & $3.27 \mathrm{E}-36$ \\
$\begin{array}{l}\text { Residual } \\
\text { Total }\end{array}$ & 31 & $9.05 \mathrm{E}+19$ & $2.92 \mathrm{E}+18$ & & \\
\hline
\end{tabular}

Table 8 regression parameters

\begin{tabular}{lllllll}
\hline & Coefts & Standard error & $\begin{array}{l}\mathrm{t} \\
\text { Stat }\end{array}$ & $\begin{array}{l}\text { P- } \\
\text { value }\end{array}$ & $\begin{array}{l}\text { Lower } \\
95 \%\end{array}$ & $\begin{array}{l}\text { Upper } \\
95 \%\end{array}$ \\
\hline $\begin{array}{l}\text { Inter } \\
\text {-ccept }\end{array}$ & $1.01 \mathrm{E}+09$ & $3.35 \mathrm{E}+08$ & 3.01 & 0.01 & $3.26 \mathrm{E}+08$ & $1.69 \mathrm{E}+09$ \\
Var 1 & 1.39 & 0.07 & 18.70 & 0.00 & 1.24 & 1.54 \\
Var 2 & 1.76 & 0.15 & 12.20 & 0.00 & 1.47 & 2.06 \\
\hline
\end{tabular}


From the above results, we can see that:

(1)Multiple R: correlation coefficient of regression statistical table is used to measure the degree of correlation between $\mathrm{X}$ and $\mathrm{Y}$. it is generally between - 1 and 1 . The closer to 1 , the higher the positive correlation. The result shows that there is a high positive correlation between them;

(2)As for the significance F of ANOVA table, the results show that the $\mathrm{p}$ value of $\mathrm{F}$ significant statistic is $3.27 \mathrm{e}-36$, which is less than the significance level of 0.05 , indicating that the regression equation obtained in this regression has significant effect;

(3)As for the P-value of the regression parameter table, it can be seen from the table that the P values of the $\mathrm{T}$ statistics of the two independent variables are $2.07 \mathrm{e}-18$ and 2.41e-13 respectively, which are far less than the significance level of 0.05 , so the two independent variables are related to $\mathrm{Y}$.

After regression analysis, the improved formula of default point is obtained:

$$
D=1.391157 S D+1.763017 L D
$$

\subsection{Empirical Study on modified KMV model}

According to the new default point of each sample company, the new default distance is calculated and compared with the original default distance, as shown in table 9.

Table 9 Comparison of default distance before and after amendment

\begin{tabular}{|c|c|c|c|c|}
\hline Company & Year & $\begin{array}{l}\text { Revised } \\
\text { default } \\
\text { point/ } \\
\text { hundred } \\
\text { million } \\
\text { RMB }\end{array}$ & $\begin{array}{l}\text { Default } \\
\text { distance }\end{array}$ & $\begin{array}{l}\text { Corrected } \\
\text { default } \\
\text { distance }\end{array}$ \\
\hline $\begin{array}{l}\text { Hengyi } \\
\text { Petrochemical }\end{array}$ & 2019 & 848.07 & 2.91 & 2.84 \\
\hline Royal Group & 2019 & 37.08 & 2.55 & 2.52 \\
\hline $\begin{array}{l}\text { ST baling } \\
\text { *Galaxy }\end{array}$ & 2019 & 14.08 & 1.51 & 1.50 \\
\hline $\begin{array}{l}\text { Biomedical } \\
\text { Investment } \\
\text { GUILIN LAYN }\end{array}$ & 2019 & 21.79 & 1.70 & 1.68 \\
\hline $\begin{array}{l}\text { NATURAL } \\
\text { INGREDIGENTS }\end{array}$ & 2019 & 12.30 & 1.88 & 1.88 \\
\hline $\begin{array}{l}\text { Zanthoxylum } \\
\text { nitridum } \\
\text { Guangxi Fenglin }\end{array}$ & 2019 & 9.00 & 2.56 & 2.55 \\
\hline $\begin{array}{l}\text { Wood Industry } \\
\text { Group }\end{array}$ & 2019 & 17.70 & 3.79 & 3.76 \\
\hline $\begin{array}{l}\text { Guangxi Hechi } \\
\text { Chemical }\end{array}$ & 2019 & 4.34 & 2.51 & 2.50 \\
\hline $\begin{array}{l}\text { Nanfang Black } \\
\text { Sesame Group }\end{array}$ & 2019 & 36.56 & 1.99 & 1.96 \\
\hline NNSUGAR & 2019 & 74.47 & 2.01 & 1.93 \\
\hline $\begin{array}{l}\text { Guilin Sanjin } \\
\text { Pharmaceutical }\end{array}$ & 2019 & 9.07 & 5.15 & 5.14 \\
\hline $\begin{array}{l}\text { Guilin Seamild } \\
\text { Foods }\end{array}$ & 2019 & 4.40 & 3.13 & 3.13 \\
\hline $\begin{array}{l}\text { Nanning } \\
\text { Chemical } \\
\text { Industry }\end{array}$ & 2019 & 1.15 & 3.46 & 3.46 \\
\hline
\end{tabular}

\begin{tabular}{|c|c|c|c|c|}
\hline $\begin{array}{l}\text { Guilin Fuda } \\
\text { Oriental Times }\end{array}$ & 2019 & 15.46 & 2.85 & 2.84 \\
\hline $\begin{array}{l}\text { Media } \\
\text { Corporation }\end{array}$ & 2019 & 7.40 & 1.73 & 1.72 \\
\hline $\begin{array}{l}\text { Liuzhou Iron And } \\
\text { Steel }\end{array}$ & 2019 & 215.11 & 2.59 & 2.56 \\
\hline LiuGong Group & 2019 & 282.42 & 3.34 & 3.24 \\
\hline $\begin{array}{l}\text { Hengyi } \\
\text { Petrochemical }\end{array}$ & 2020 & 940.03 & 2.14 & 2.08 \\
\hline Royal Group & 2020 & 55.37 & 2.14 & 2.11 \\
\hline $\begin{array}{l}\text { ST baling } \\
* \text { Galaxy }\end{array}$ & 2020 & 9.93 & 1.99 & 1.97 \\
\hline $\begin{array}{l}\text { Biomedical } \\
\text { Investment }\end{array}$ & 2020 & 32.15 & 2.32 & 2.26 \\
\hline $\begin{array}{l}\text { GUILIN LAYN } \\
\text { NATURAL } \\
\text { INGREDIGENTS }\end{array}$ & 2020 & 19.42 & 2.06 & 2.05 \\
\hline $\begin{array}{l}\text { Zanthoxylum } \\
\text { nitridum }\end{array}$ & 2020 & 6.30 & 2.21 & 2.21 \\
\hline $\begin{array}{l}\text { Guangxi Fenglin } \\
\text { Wood Industry } \\
\text { Group }\end{array}$ & 2020 & 13.53 & 2.72 & 2.71 \\
\hline $\begin{array}{l}\text { Guangxi Hechi } \\
\text { Chemical }\end{array}$ & 2020 & 2.79 & 2.39 & 2.38 \\
\hline $\begin{array}{l}\text { Nanfang Black } \\
\text { Sesame Group }\end{array}$ & 2020 & 34.44 & 1.87 & 1.84 \\
\hline NNSUGAR & 2020 & 80.40 & 2.18 & 2.11 \\
\hline $\begin{array}{l}\text { Guilin Sanjin } \\
\text { Pharmaceutical }\end{array}$ & 2020 & 14.09 & 3.08 & 3.08 \\
\hline $\begin{array}{l}\text { Guilin Seamild } \\
\text { Foods } \\
\text { Nanning }\end{array}$ & 2020 & 4.94 & 1.13 & 1.12 \\
\hline $\begin{array}{l}\text { Chemical } \\
\text { Industry }\end{array}$ & 2020 & 0.60 & 4.36 & 4.36 \\
\hline $\begin{array}{l}\text { Guilin Fuda } \\
\text { Oriental Times }\end{array}$ & 2020 & 16.27 & 2.40 & 2.39 \\
\hline $\begin{array}{l}\text { Media } \\
\text { Corporation }\end{array}$ & 2020 & 22.34 & 2.12 & 2.06 \\
\hline $\begin{array}{l}\text { Liuzhou Iron And } \\
\text { Steel }\end{array}$ & 2020 & 557.70 & 2.96 & 2.79 \\
\hline LiuGong Group & 2020 & 315.57 & 3.04 & 2.96 \\
\hline
\end{tabular}

\subsection{Rationality test of modified KMV model}

In order to verify the rationality of the modified KMV model in measuring the credit risk of Guangxi manufacturing industry, five ST companies with continuous losses and marked with special treatment are selected as the risk group, and other companies as the control group. The results are shown in table 10 .

Table 10 rationality test of modified KMV model

\begin{tabular}{lll}
\hline & $\begin{array}{l}\text { Average } \\
\text { default } \\
\text { distance }\end{array}$ & $\begin{array}{l}\text { Average } \\
\text { expected } \\
\text { default rate }\end{array}$ \\
Risk group & 2.39 & 0.02 \\
Control group & 2.58 & 0.02 \\
Total & 2.52 & 0.02 \\
\hline
\end{tabular}


Thus, the average default distance of the risk group is significantly less than that of the control group, and the average expected default rate is significantly higher than that of the control group. Due to the special treatment of ST companies, it can show that the credit risk is high to a certain extent. Therefore, the test results of the model show that the modified KMV model can better measure the credit risk level of Guangxi manufacturing industry.

\section{Conclusion and discussion}

\subsection{Conclusion}

Using the above data, we can get the change of credit risk level of the Guangxi Zhuang Autonomous Region manufacturing industry in the past 2019-2020 years under the revised KMV model in the past three years, as shown in the table11.

Table 11 empirical results under the modified KMV model

\begin{tabular}{lrcc}
\hline & & 2019 & 2020 \\
\hline $\begin{array}{l}\text { Average } \\
\text { distance } \\
\text { correction }\end{array}$ & $\begin{array}{r}\text { default } \\
\text { after }\end{array}$ & 2.66 & 2.38 \\
$\begin{array}{l}\text { Revised } \\
\text { expected } \\
\text { rate }\end{array}$ & $\begin{array}{r}\text { average } \\
\text { default }\end{array}$ & 0.02 & 0.02 \\
\hline
\end{tabular}

It can be seen that the trend is consistent with the empirical results of the traditional KMV model. From 2019 to 2020, the average default distance of the sample companies decreases from 2.6597 to 2.3820 , and the average expected default rate increases from 0.01567 to 0.0196 .

Based on the empirical study of the traditional KMV model and the modified KMV model of the manufacturing listed companies in Guangxi, and after proving the rationality of the model, the following conclusions are drawn:

(1)The expected default rate of the sample companies does not exceed 0.2. According to the corresponding relationship between the expected default rate and standard \& Poor's rating, Moody's rating, the overall credit risk of Guangxi manufacturing industry is low, the risk control ability is strong and the enterprise innovation environment performed well;

(2)Influenced by COVID-19, the overall credit risk of Guangxi's manufacturing industry increased in 2020. Although the overall situation is good, we still need to make timely control over credit risk so as not to cause losses, so as not to deeply restrict the improvement of enterprise innovation ability.

\subsection{Discussion}

Although the traditional KMV model is not fully applicable in China's market and the default point is modified, the KMV model itself has inherent defects, and the modified model still needs to be improved:

(1)The premise of normal distribution of asset value.
KMV model assumes that asset value follows normal distribution. This is not the case in reality. The stock price is often controlled by the makers, there is a lot of asymmetric information, and asset value is not always subject to normal distribution;

(2)Different types of debt cannot be distinguished. KMV model can't distinguish the priority of debt repayment, whether there is guarantee or not, and can't distinguish different types of debt. The model's trial range is small, and the assumption of debt structure is unreasonable, so it has an impact on the accuracy of the test results and the analysis of the influence mechanism of enterprise innovation is not objective enough;

(3)For the calculation of the stock price volatility, this paper uses the historical data method to estimate, using the sample standard deviation of the logarithmic rate of return as its value. However, the stock price is changeable, and emergencies will seriously affect the change of the stock price. Therefore, simply taking the logarithmic potential of the closing price will have an impact on the results, and it is not accurate to evaluate the credit risk of manufacturing industry and its influence on enterprise innovation.

(4)For the determination of the default distance, this paper directly selects the calculation method given by KMV company. Liu Bo (2010) points out three methods to calculate the default distance, and finally uses the continuous rate of return of assets $u$ to obtain the most suitable judgment formula for China's actual situation ${ }^{[9]}$.

$$
D D=\frac{\ln \left(\frac{V_{A}}{D}\right)+\left(u-\frac{\sigma_{A}{ }^{2}}{2}\right) T}{\sigma_{A} \sqrt{T}}
$$

Therefore, how to further modify the KMV model to make it more suitable for China's actual situation remains to be further studied, in order to further analyze the impact of emergencies on manufacturing credit risk and enterprise innovation ability, and accordingly put forward countermeasures.

\section{Acknowledgments}

This paper is the periodical results of the research subject of Guangxi Philosophy and Social Science Planning: "Research on Guangxi Regional Financial Risk Prevention" (17FGL005), and the national education science "13th Five-Year Plan": "Research on Innovation and Practice of Cooperative Training Mechanism of High-Skilled Applied Financial Talents between China and ASEAN" (FIB170502),

\section{Reference}

1. Yan f. 1. Shi y.m. Economic policy uncertainty, financial development and enterprise innovation. [J/OL].Journal of financial development research,2021(5)18-26.

2. Wang L.1., Shan Y.k.. Research on the evaluation of financial risk of listed companies by using "Z-score method" -- taking coal industry as an example [J]. China business review, 2017 (19): 111-112

3. Wang M.q.. 5C evaluation method of accounts 
receivable management and its supplement [J]. Operation and management, 2017 (07): 29-32

4. Jiang L. Research on credit risk prediction of supply chain finance based on Cox model [D]. Nanhua University, 2019.

5. Jiang L. 1., Li b. z. Research on financial credit risk of agricultural product supply chain based on improved KMV model [J]. Journal of Fujian agriculture and Forestry University (PHILOSOPHY AND SOCIAL SCIENCES EDITION), 2021,24 (01): 41-49.

6. Zhang Y. t. Empirical analysis on credit risk measurement of GEM companies based on KMV model [D]. Guizhou University of Finance and economics, 2018.

7. Shi D. c. Empirical analysis on credit risk of mining listed companies based on KMV model [D]. Northwest University for nationalities, 2019.

8. Ge T. f, Bai Z.s. Xu J. Credit risk evaluation of listed companies based on KMV Model -- Taking artificial intelligence industry as an example [J]. Journal of Chaohu University, 2020,22 (06): 45-53.

9. Liu B. Empirical analysis on credit risk measurement of Chinese Listed Companies Based on KMV model [J]. Science, technology and engineering, 2010, 10 (3): 843-843. 